\title{
The Renin-Angiotensin System in the Fetal Lamb
}

\author{
Fred G. Smith, Jr., ${ }^{[45]}$ Andrei N. Lupu, Luciano Barajas, Robert Bauer, and Richard A. Bashore \\ Gwynne Hazen Cherry Renal Research Laboratory, Department of Pediatrics, Department of Surgery/Urology, Department of Biology, \\ Department of Anesthesiology and Department of Obstetrics and Gynecology, University of California at Los Angeles, School of \\ Medicine, Los Angeles, California, USA
}

\begin{abstract}
Extract
This study was designed to investigate the renin-angiotensin system in the fetal lamb. Simultaneous measurements of plasma renin activity (PRA) were carried out in seven acute fetal-maternal sheep preparations at 91, 100, 104, 112, 124, 142, and 145 days of gestational age, respectively (term 145 days). The mean fetal PRA in this group was $4.87 \mathrm{~m} \mu / \mathrm{ml}$ as compared with $1.58 \mathrm{~m} \mu / \mathrm{ml}$ for the maternal plasma. PRA was also measured simultaneously in three intrauterine nonstressed fetuses. Six days after insertion of catheters, the fetal PRA was $9.0,9.2$, and $8.75 \mathrm{~m} \mu / \mathrm{ml}$, respectively, and the maternal PRA was $0.4,4.5$, and $3.75 \mathrm{~m} \mu / \mathrm{ml}$, respectively.

The fetal response to aortic constriction was studied in three fetuses and the PRA increased from control values of $4.8,5.5$, and $22.2 \mathrm{~m} \mu / \mathrm{ml}$ to $8.0,11.5$, and 34.5 $\mathrm{m} \mu / \mathrm{ml}$, respectively, within $15 \mathrm{~min}$ after initiation of the aortic constriction and continued to rise to maximum levels of $11.8,25.5$, and $38.0 \mathrm{~m} \mu / \mathrm{ml}$, respectively. PRA then decreased after release to near control levels. The maternal PRA did not change significantly during the study period. PRA was also measured in the in utero fetus after decreasing the blood volume $8-10 \%$ by acute controlled bleeding, and the PRA rose from control values of 6.0 and $4.2 \mathrm{~m} \mu / \mathrm{ml}$ to 40.0 and $54.4 \mathrm{~m} \mu / \mathrm{ml}$ within 15 min after blood loss, followed by a return towards control values over the subsequent 30 min.

Morphologic studies in five fetuses, 91-141 days of gestational age, indicate that the juxtaglomerular apparatus contains Bowie-positive smooth muscle granular cells and appears well developed in the fetal kidney by light and electronmicroscopy.

These studies, therefore, indicate that the renin-angiotensin system is present during fetal development in the sheep and also demonstrate that the fetus does respond to stimuli which, in the adult, result in renin release. However, further studies will be necessary in order to establish a definitive physiologic role for renin in the fetus.
\end{abstract}

\section{Speculation}

The renin-angiotensin system appears to be well developed during fetal development. These observations suggest that the enhanced activity of the renin-angiotensin system may play a role in the control of renal hemodynamics and fluid and electrolyte homeostases in the developing fetus.

\section{Introduction}

Little is known about the morphologic or physiologic control of the renin-angiotensin system in the developing fetus.
A number of morphologic investigations have demonstrated the presence of juxtaglomerular granules in developing animal fetuses and neonates $[1,11,12,26$, $27,29,35,38]$, which indicates that renin may be 
present in the developing fetal kidney. Granger et al. [17], using newborn dogs, showed that PRA was significantly higher for the first 2 weeks of extrauterine life when compared with the values found in adult dogs. More recently, Trimper et al. [37] demonstrated that the fetal kidney was capable of releasing renin in response to furosemide as early as 110 days of gestational age (term, 145 days).

The present study was designed to investigate the activity and control of the renin-angiotensin system in the fetal lamb.

\section{Materials and Methods}

\section{Acute Experiments}

Seven ewes of mixed Western breed were included in the "acute" studies. The gestational ages of the fetuses at the time of study were 91, 100, 104, 112, 124, 142 , and 145 days, respectively. Before the experimental procedure, all hay and grain were withheld for 24 hr and water was permitted ad libitum. Surgery was performed under spinal anesthesia $(8 \mathrm{mg}$ Pontocaine in hypertonic glucose). The uterus was exposed through a small midline abdominal incision and the fetal hind leg located by palpation through the uterine wall. One fetal hind leg was delivered through a small hysterotomy and polyvinyl catheters were inserted into the pedal artery and vein and advanced to the level of the common iliac artery and vein. An arterial blood specimen was obtained immediately after the artery was cannulated for measurement of PRA and a second sample was obtained in $30 \mathrm{~min}$ to provide two control specimens in the nonmanipulated fetus.

In three experiments involving aortic constriction, the fetus was delivered onto a heated pan under a radiant heat hood. Catheters were placed as described above and a temperature probe was placed in the rectum or esophagus for continuous temperature monitoring. A small incision was made in the flank of the fetus immediately below the 12 th $\mathrm{rib}$ and the renal arteries were exposed. A polyethylene constrictor was placed around the abdominal aorta immediately proximal to the renal arteries. Catheters were placed in the carotid artery and in the abdominal aorta distal to the renal arteries for continuous monitoring of arterial pressure via pressure transducers (Statham P23Db [40]) and recorded on an Offner recorder [41]. A third catheter was placed in the inferior vena cava proximal to the renal veins (Fig. 1).

The PRA was measured in two fetuses before and after suprarenal aortic constriction. Two arterial blood specimens were obtained as controls and immediately following the second control blood sample, the aorta was constricted until the lower abdominal arterial pressure was $10-12 \mathrm{~mm} \mathrm{Hg}$ lower than the carotid artery pressure. The constriction was maintained for $30 \mathrm{~min}$ and released. Venous blood was obtained every 15 min for 90 min for PRA from a catheter placed 2 $\mathrm{cm}$ proximal to the renal vein.

The PRA was also measured after acute hemorrhage in two fetuses. After two control venous blood specimens, the fetal-placental blood volume was reduced an estimated $8-10 \%$ and venous blood samples were obtained every $15 \mathrm{~min}$ for $45 \mathrm{~min}$. This was followed by 30 min of aortic constriction as described above. Two venous blood specimens were then obtained every 15 min for $30 \mathrm{~min}$.

Arterial blood for $\mathrm{pCO}_{2}, \mathrm{pH}, \mathrm{pO}_{2}$, and base excess was obtained and arterial pressure, pulse rate, and body temperature were monitored in both the fetus

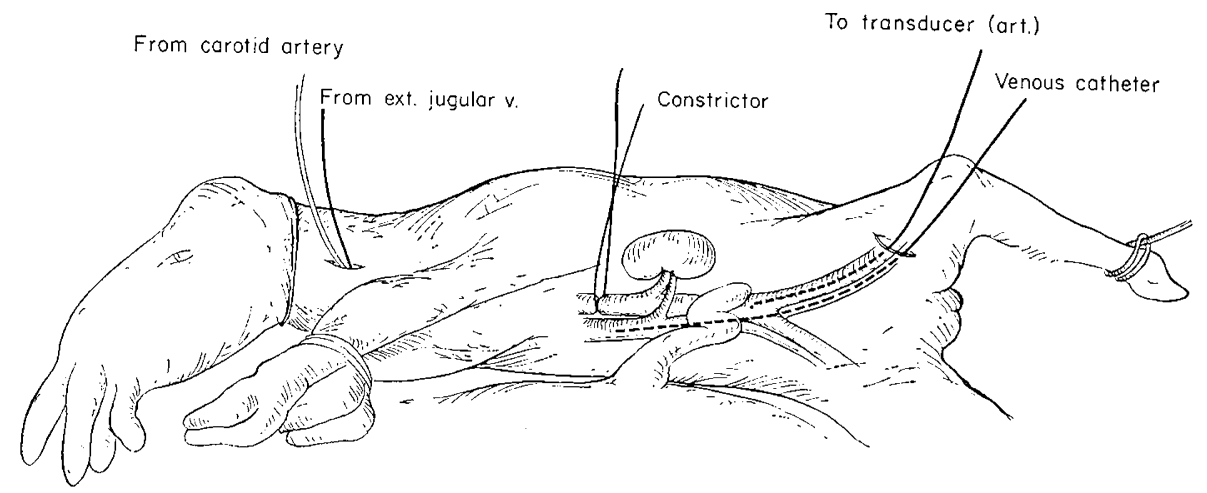

Fig. 1. The lamb fetus illustrating locations of catheters and aortic constrictor. The head of the fetus is covered by a water filled rubber glove. ext.: external; $v .:$ vein; art. arterial. 
and ewe throughout the experimental period in order to follow the condition of the fetus and ewe.

\section{Chronic Experiments}

In three animals, subjects C16, C18, and C19, the insertion of the catheters was carried out as described above, using sterile surgical technique, and the catheters were brought out through the uterine incision and peritoneum of the ewe. All wounds were closed with 10 chromic suture, and the catheters were brought out through the flank of the ewe via a subcutaneous tunnel. All catheters were heparinized and plugged with stainless steel plugs, secured in a small cloth envelope sutured to the maternal skin over the flank. The heparin solution was withdrawn and catheters were irrigated with normal saline solution before each blood sample was obtained. The ewe was returned to a confinement cage and given feed and water ad libitum. Six days were allowed for recovery before fetal blood samples or urine were collected. This provided a method for sequential study of the nonstressed intrauterine fetus. On the 6 th day after surgery, arterial blood was obtained from the fetus and ewe on 2 successive days for PRA.

PRA was determined by the method of Boucher et al. [5], with minor modifications as described previously [28]. The renin determinations were performed in one investigator's laboratory (AL) and the variation from the mean for 16 aliquots of pool serum was $\pm 2 \%$. In order to prevent excessive blood loss, especially from the fetal lamb, blood samples were limited to 2 $\mathrm{cc}$ and PRA determinations were performed on $1 \mathrm{cc}$ plasma.

\section{Histologic Studies}

Renal tissue was obtained from three fetuses at 114, 124, and 130 days of gestational age and from two pregnant ewes. For light microscopy, tissue was fixed in Helly's solution, embedded in paraffin and stained with Bowie stain, according to Hartroft's procedure [20]. For electronmicroscopy, the tissue was fixed by immersion in $10 \%$ glutaraldehyde in phosphate buffer, and postfixed in osmium tetroxide in phosphate buffer and embedded in Epon. Paraffin-embedded sections were examined with the light microscope, under oil immersion, and Epon-embedded ultrathin sections, cut with an MT II microtome fitted with a diamond knife, were examined with a Siemens [42] Elmiskope 1 electronmicroscope.

\section{Results}

\section{PRA in Fetus and Ewe}

The PRA in the fetuses is compared with that in the ewes in Figure 2. All of the $E$ series of experiments were performed utilizing the acute fetal preparation. The

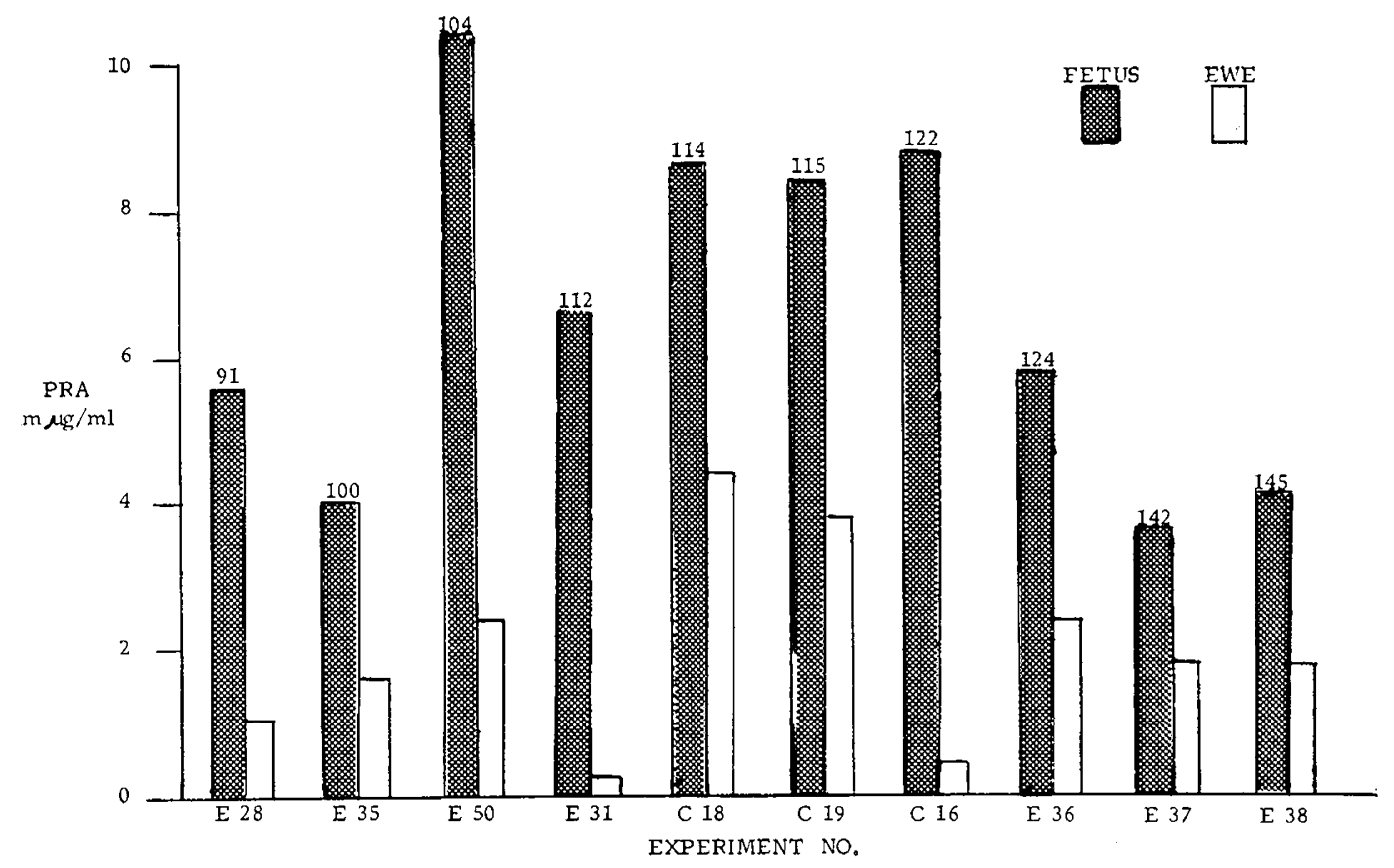

Fig. 2. Plasma renin activity $(P R A)$ in 10 lamb fetuses and ewes. Gestational age is indicated on the top of the fetal bar graph. 
mean fetal PRA in this group was $4.87 \mathrm{~m} \mu / \mathrm{ml}$ and the maternal, $1.58 \mathrm{~m} \mu / \mathrm{ml}$, respectively. The highest PRA was found in the three chronic nonstressed intrauterine fetuses, 9.0, 9.2, and $8.75 \mathrm{~m} \mu / \mathrm{ml}$, respectively, and the corresponding maternal PRA was $0.4,4.5$, and 3.75 $\mathrm{m}_{\mu} / \mathrm{ml}$, respectively. PRA was also measured in four nonpregnant ewes and the activities ranged from 0.3 to $2.1 \mathrm{~m} \mu / \mathrm{ml}$.

The fetal blood $\mathrm{pH}, \mathrm{pCO}_{2}$, and $\mathrm{pO}_{2}$ were measured at the time of sampling for PRA. All values were within the ranges reported previously by Blechner et $a l$. in the nonstressed fetus [4].

\section{Response to Aortic Constriction}

The fetal response to aortic constriction was studied in three acute fetal preparations at 120, 130, and 145 days of gestational age. PRA increased rapidly after constriction in all fetuses and continued to rise during the 15-min period after release of the constrictor. PRA then decreased towards control values. The maternal PRA did not change significantly during the studies (Figs. 3 and 4).

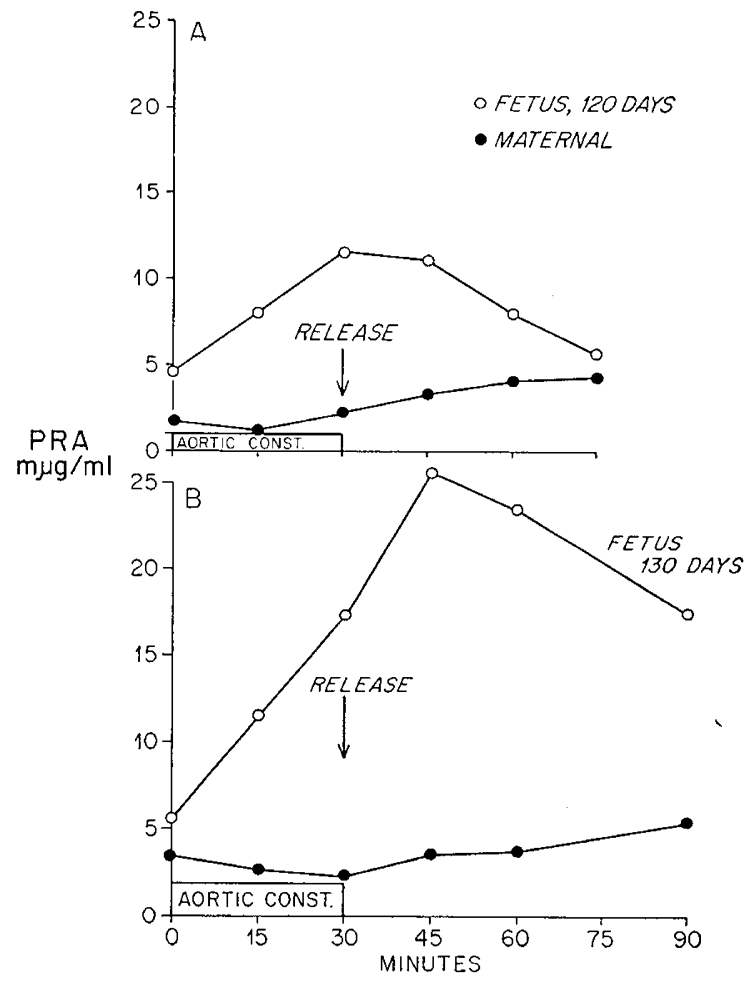

Fig. 3. The effect of aortic constriction on plasma renin activity $(P R A)$ in the intact fetal lamb and ewe.

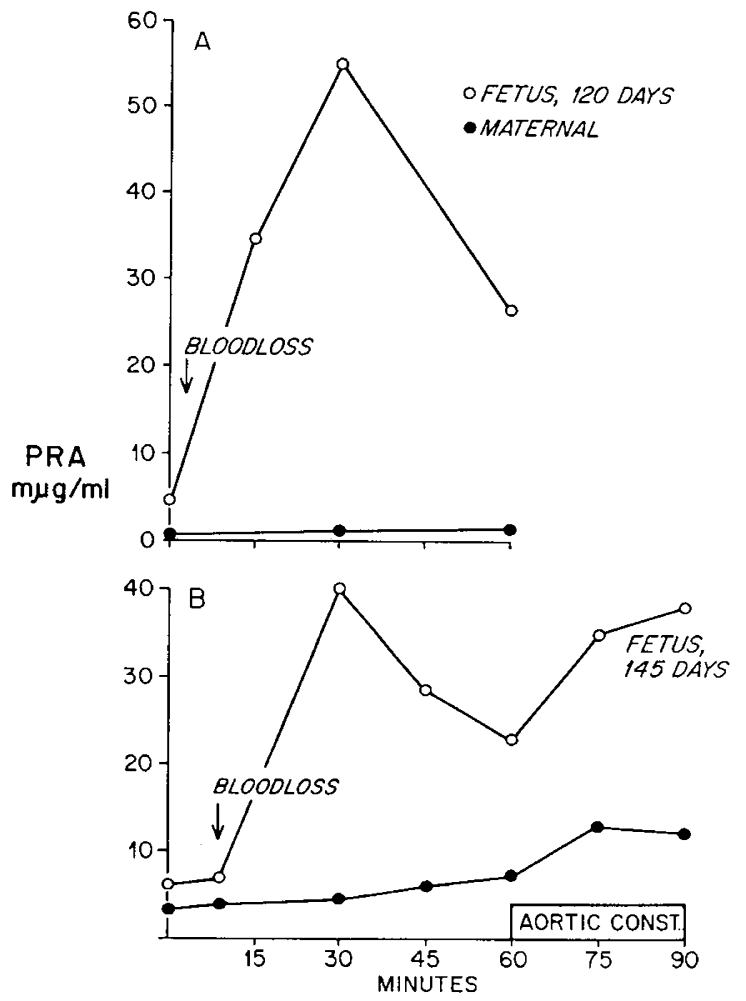

Fig. 4. The effect of acute hemorrhage on plasma renin activity PRA in the intact fetal lamb and ewe.

\section{Response to Acute Hemorrhage}

PRA was also measured after acute blood loss in two fetal preparations at 120 and 145 days of gestational age (Fig. 4). After an 8-10\% decrease in blood volume, there was a striking rise in PRA within $15 \mathrm{~min}$, followed by a return towards control values over the next $30 \mathrm{~min}$. PRA increased from control values of 6 and $5.5 \mathrm{~m} \mu / \mathrm{ml}$ to 40 and $55.2 \mathrm{~m} \mu / \mathrm{ml}$, respectively, then decreased in $30 \mathrm{~min}$ to 22 and $27.8 \mathrm{~m}_{\mu} / \mathrm{ml}$, respectively.

\section{Morphologic Studies of Fetal Juxtaglomerular Appara- tus $(J G A)$}

A well developed JGA was observed in four fetuses studied at 96, 112, 124, and 142 days of gestational age. Light microscopy studies revealed characteristic Bowiepositive granular cells (juxtaglomerular cells, renin cells) demonstrated in the vascular component of the JGA (Fig. 5). The highest juxtaglomerular cell count was observed at 96 days of gestational age. The granules were seen preferentially in the extraglomerular mesangial region which is well developed in the fetal 


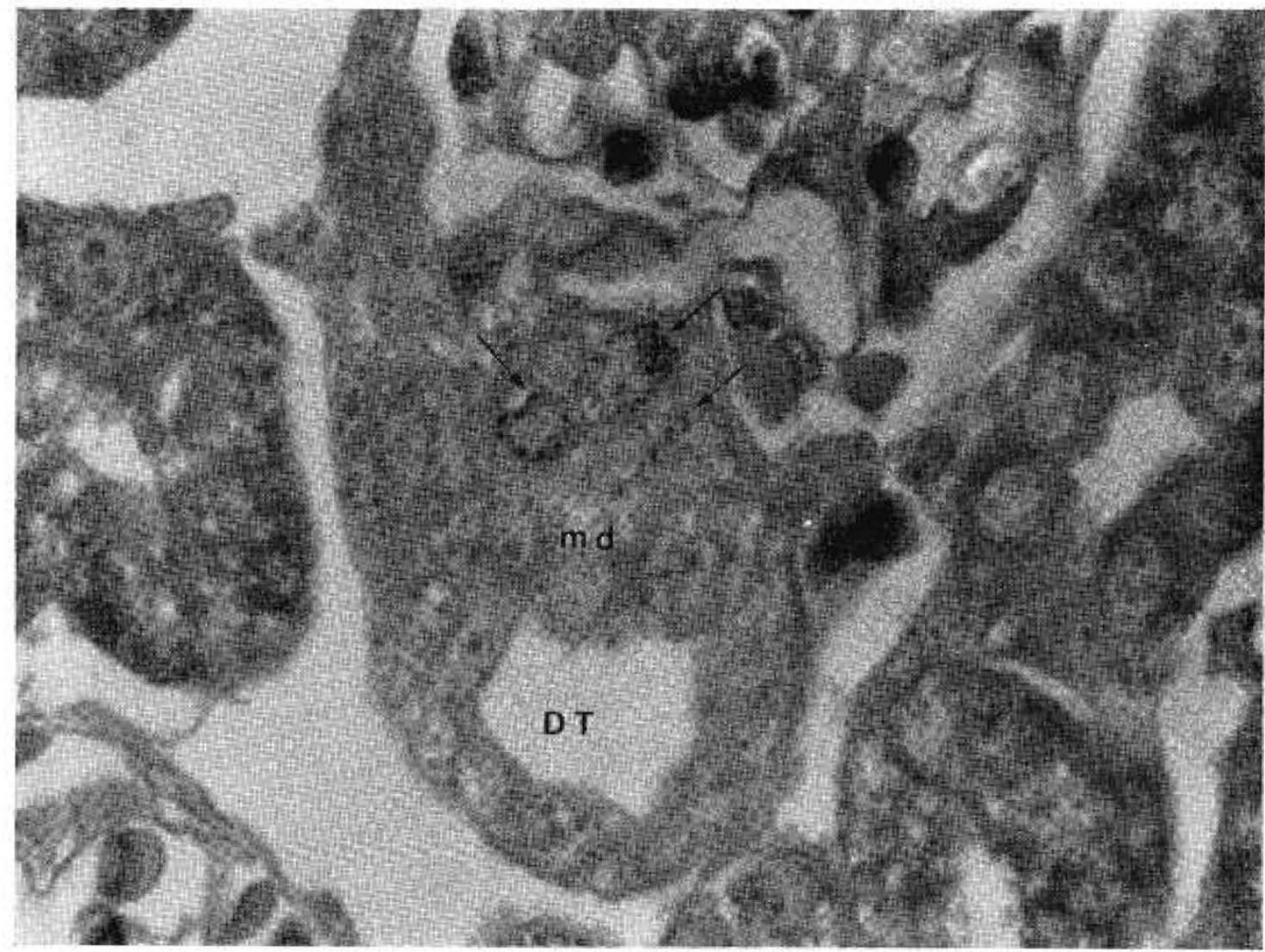

Fig. 5. Juxtaglomerular apparatus of fetal kidney 124 days old. Granular cells are seen (arrows). They are in the mesangial portion of the vascular component of the juxtaglomerular apparatus. The distal tubule $(D T)$ is in contact with the mesangial region. A well developed macula densa $(m d)$ is seen at the site of contact. Bowie stain, $\times 1,000$.

lamb and in extensive contact with the distal tubule (Figs. 5 and 6). Granular cells in contact with the distal tubule were seen and this latter observation was confirmed by electron microscopy studies. Only the basement membrane separates the granular from the tubular cells. The granular cells are rich in smooth muscle elements and their granules clearly correspond to the Bowie-positive granules observed under the light microscope. The granules measure $0.5 \mu \mathrm{m}$.

\section{Morphologic Studies of Maternal JGA}

For comparison purposes, a light and electron microscopic study of the maternal JGA was done. By light microscopy, Bowie-positive granular cells were seen in the maternal JGA (Fig. 7). With the electron microscope (Fig. 8), the granular cells appear as modified smooth muscle cells containing characteristic secretory granules. The granules of the maternal cells measure the same as the fetal, approximately $0.5 \mu \mathrm{m}$.

\section{Discussion}

A number of recent studies have suggested an enhanced activity of the renin-angiotensin system in the newborn animal and human. Granger et al. [17] demonstrated that the PRA in newborn dogs was significantly higher for the first 2 weeks of extrauterine life when compared with values found in adult dogs, and Kotchen et al. [25] demonstrated in human neonates that PRA, as measured by immunoassay and bioassay, was significantly elevated during the first 6 days after delivery. Furthermore, PRA was also elevated at 3-6 weeks of age but lower than during the Ist postnatal week. Previously reported observations from our laboratory indicated that the fetal PRA values were significantly higher than the maternal PRA [33] and more recently, Trimper and Lumbers [37] demonstrated that intravenous furosemide stimulates the release of renin by the fetal lamb kidney. The latter investiga- 


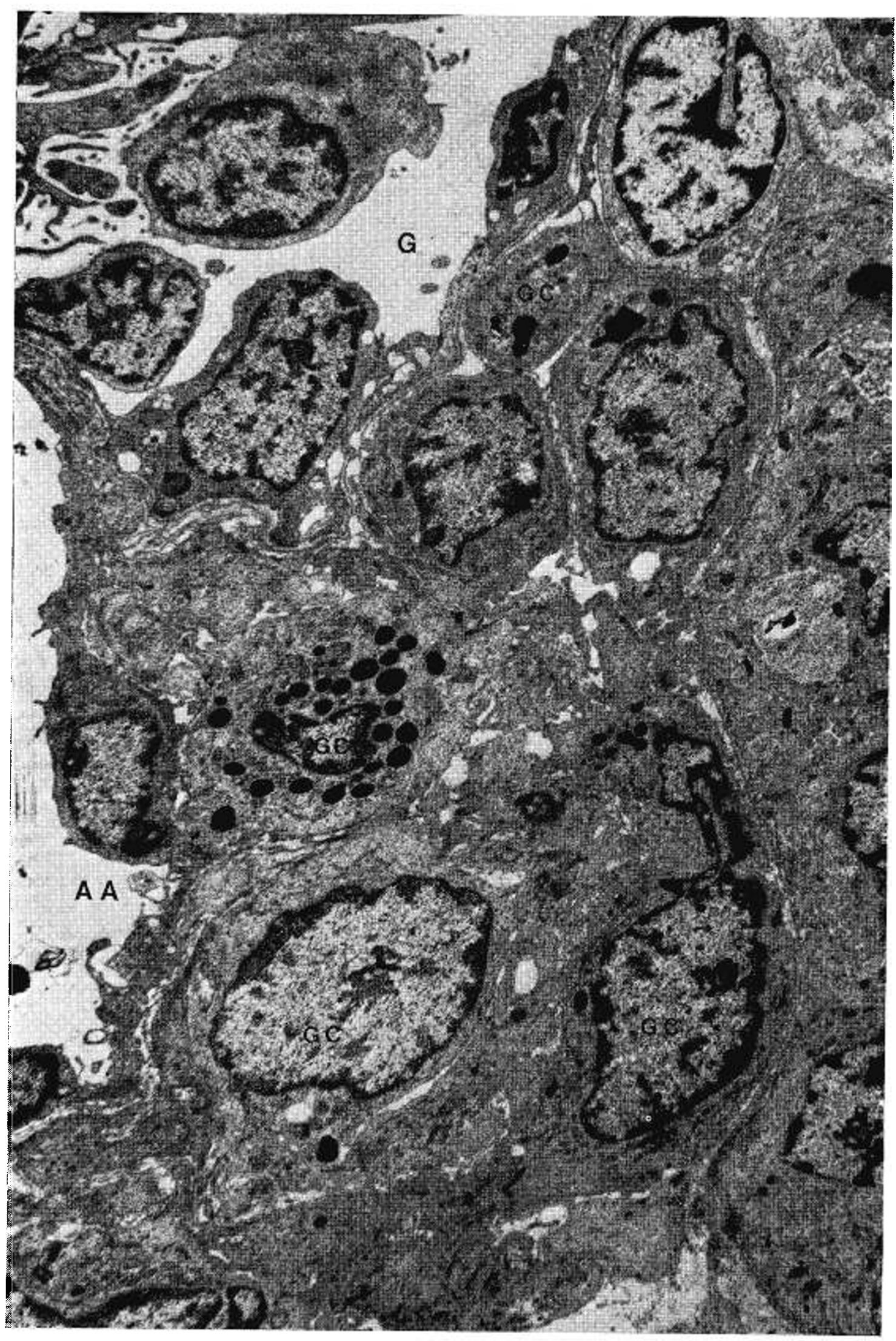

Fig. 6. Electronmicrograph of the juxtaglomerular apparatus of fetal kidney 124 days old. Numerous granular cells $(G C)$ can be seen in the mesangial region. In the lower right there is a granular cell in contact with the distal tubule. $G$; glomerulus; $A A$ : afferent arteriole. $\times \quad 8,500$. 


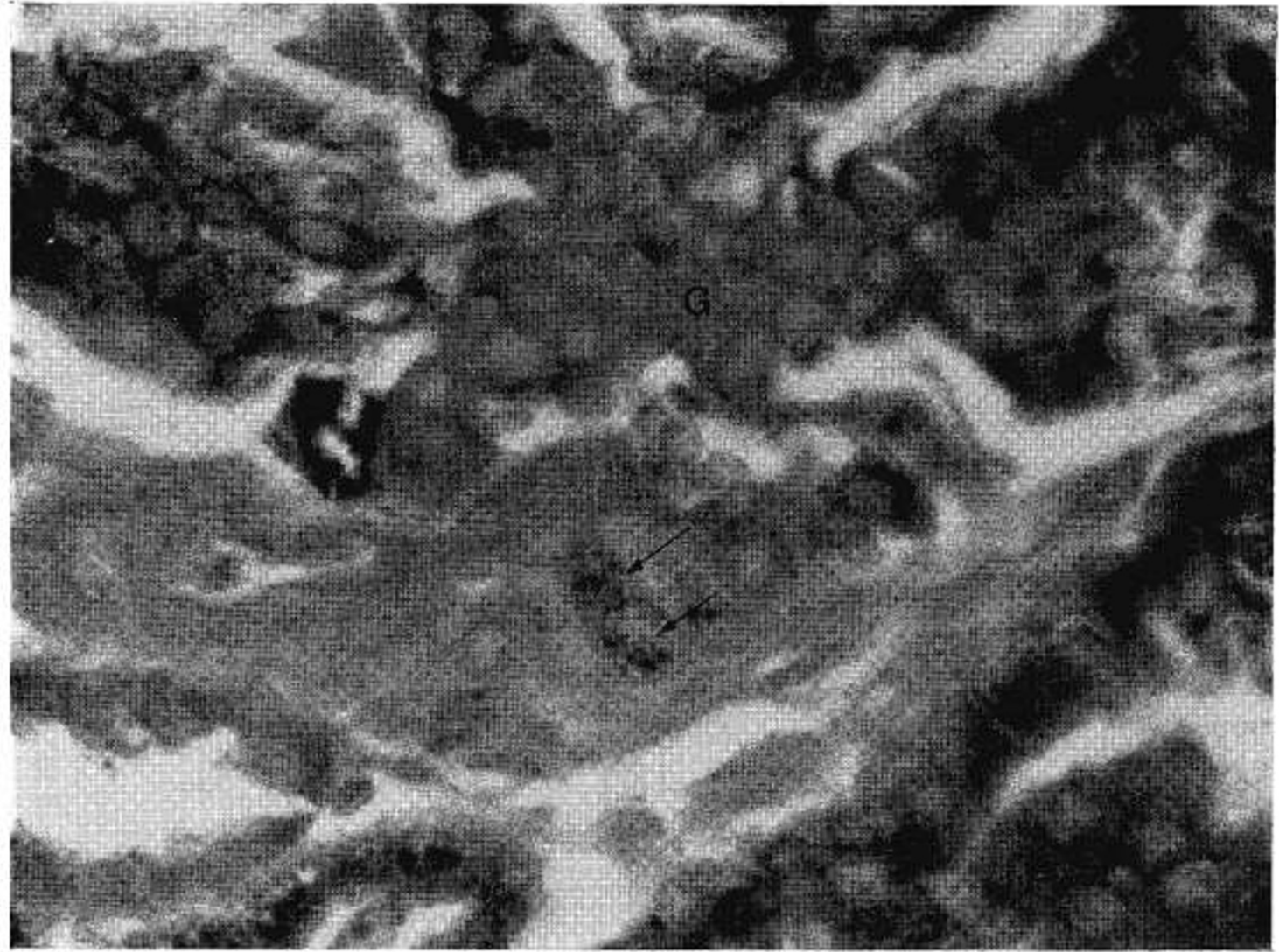

Fig. 7. Juxtaglomerular apparatus of the maternal kidney. Bowie-positive granular cells are seen in the vascular component of the juxtaglomerular apparatus at the glomerilar hilus (arrowes). The glomerulus $(G)$ is seen above the granular cells. Bowie stain, $\times 1,000$.

tors suggested that the greater responsiveness of the fetal kidney to furosemide administration in terms of renin release may indicate a role for the renin-angiotensin system in the maintenance of fetal circulatory homeostasis.

Hyperreninemia also occurs during pregnancy in humans $[6,15]$ and other mammals $[18,21]$, and the findings of high PRA during pregnancy raise the question of its origin. In addition to the maternal kidney, there are several other sources of renin in the pregnant animal and human. Brown and associates [7] detected renin in human amniotic fluid obtained near term and the renin activity in amniotic fluid was greater than in either maternal plasma or cord plasma. Renin-like material has also been demonstrated in uterine tissue from pregnant animals $[14,31]$. The fetal kidney is another obvious source of renin. Hodari et al. [22] extracted renin from the fetal dog kidney and granulated juxtaglomerular cells have been observed as early as 17 weeks of gestational age in the human fetus [27]. Granger et al. [17] demonstrated high PRA in new- born dogs and they suggested that neither placental nor uterine contribution of renin could account for the high PRA values observed in newborn dogs after $12 \mathrm{hr}$. Furthermore, these investigators demonstrated that the PRA in newborn dogs increased rapidly in response to peritoneal dialysis, using $5 \%$ dextrose and water, which indicated that the kidneys of newborn dogs are able to release renin after stimulation.

The present studies indicate that the renin-angiotensin system is well developed in the fetal lamb and further demonstrate that known stimuli, such as suprarenal aortic constriction and hemorrhage, result in renin release in the fetal state.

It is difficult to speculate concerning the stimulus for enhanced renin secretion in both the fetal and newborn state because of the controversy regarding the basic mechanism for the control of renin release. During fetal life the systemic blood pressure is low; this would support the baroreceptor theory advocated by Skinner et al. [32]. Renal blood flow in the sheep fetus is low, accounting for less than $2-8 \%$ of the total 


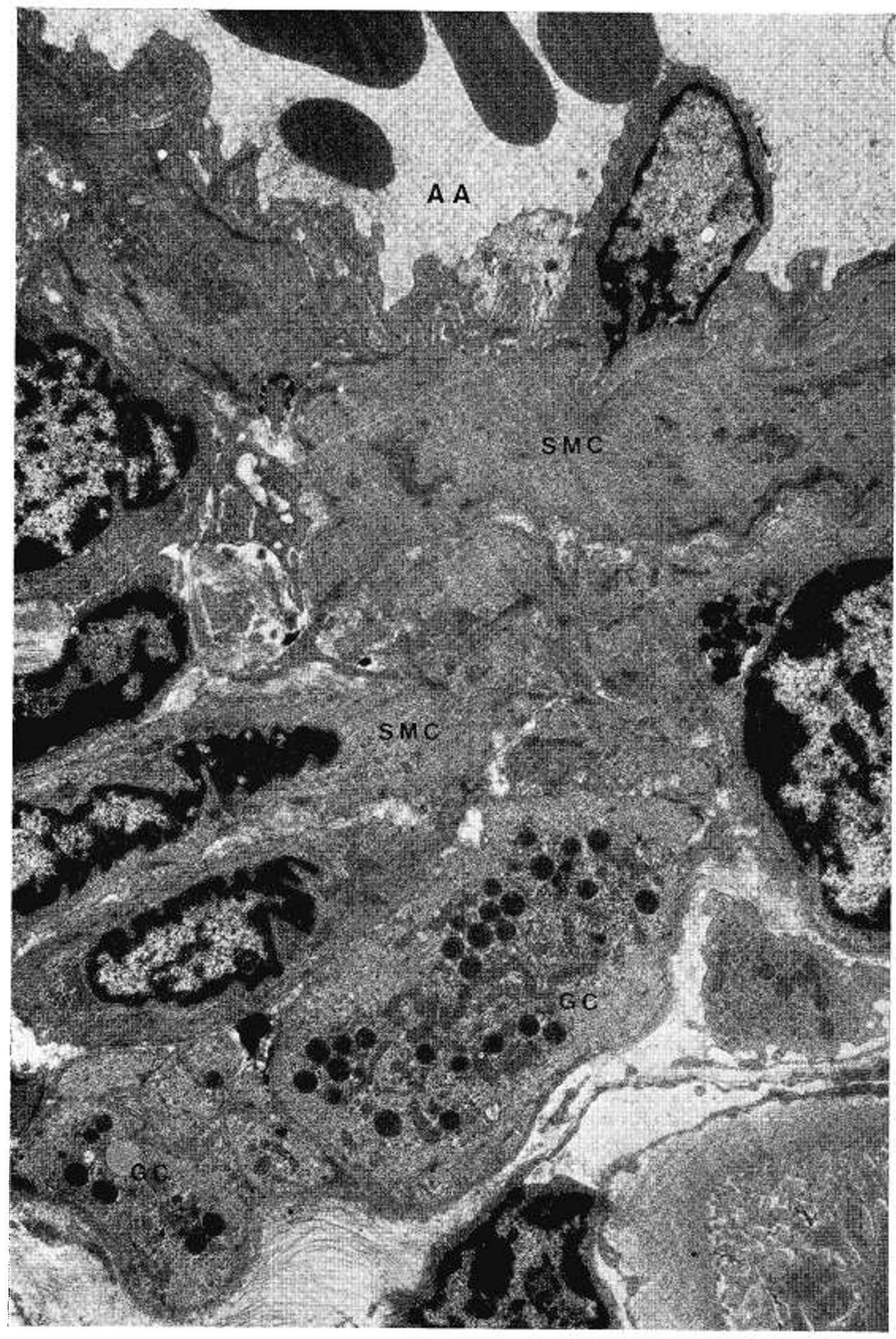

Fig. 8. Electronmicrograph of the maternal juxtaglomerular apparatus. Well granulated juxtaglomerular cells in the wall of the afferent arterial $(A A)$ are seen in the lower half of the picture. GC: granular cell; SMC: smooth muscle cell. $\quad \times 8,500$. 
cardiac output $[30,34]$. Therefore, the role played by renal "ischemia" cannot be completely dismissed [16]. Studies in our laboratory suggest that renal blood flow remains low in the sheep fetus until near term, when it appears to rise, but remains less than $10-12 \%$ of total cardiac output. The elevated renin levels found in the fetal state, therefore, may be related to hemodynamic phenomena.

It has also been demonstrated that the rate of sodium reabsorption in the proximal tubule of the infant rat is decreased [8], and studies in our laboratory indicate that sodium reabsorption is also suppressed in the sheep fetus. It is therefore likely that the delivery of sodium to the macula densa is greater in the immature kidney. Therefore, according to the macula densa theory as suggested by Thurau and Schenermann [36], this increased fractional delivery of sodium at the macula densa would promote renin release.

The well developed JGA observed in the fetal lamb does not differ essentially from that of the adult [2]. The presence in the fetus of numerous granular (renin) cells point to the fetal JGA as the likely source of fetal renin $[10,13]$. This, as well as the contact between the granular cells and the macula densa are anatomical evidence consistent with a mechanism for intrarenal control of renin secretion in the fetus similar to that in the adult $[3,39]$.

Our studies in the fetal sheep which indicate elevated PRA suggest that this alteration in the reninangiotensin system may contribute to both the increased vascular resistance and the reduction of the glomerular filtration rate and renal blood flow observed in the developing fetus and newborn animal [19]. Recent studies by Jose et al. [24] indicate that there is a progressive increase in total renal blood flow with increasing postnatal age and they suggest that this result was primarily caused by an increase in flow to cortical nephrons. They further suggested that this was in part a consequence of cortical growth; however, changes in vascular tone may also be a contributing factor. Horster and Voltin [23] demonstrated recently that the subcapsular nephrons in dogs are patent by 21 days of age. In addition, Carriere and Friborg [9] have demonstrated that the outer cortex is more sensitive to the infusion of angiotensin than the inner cortex, so that a higher proportion of glomerular filtrate is diverted to the juxtamedullary glomeruli. These studies, therefore, suggest that the elevated fetal PRA may be also related to the distribution of renal blood to the juxtamedullary glomeruli in the immature kidney.

\section{Summary}

Maternal and renin activities in fetal plasma were measured simultaneously in seven acute and three chronic maternal fetal sheep preparations at various stages of gestation. The fetal PRA was higher than the maternal in all preparations. In addition, it was shown that the fetus responds to stimuli which, in the adult, result in renin release. Morphologic studies in five fetuses indicated that the juxtaglomerular apparatus contains Bowie-positive smooth muscle granular cells and appears well developed in the fetal kidney as early as 91 days of gestational age (term 145 days). Further studies will be necessary in order to establish a specific physiologic role for renin in the fetus.

\section{References and Notes}

1. Albrecht, I.: Granularity of the juxtaglomerular apparatus in newborn rats. The effect of sodium and potassium treatment during pregnancy. Biol. Neonatorum 12: 233 (1968).

2. Barajas, L.: The ultrastructure of the juxtaglomerular apparatus as disclosed by three-dimensional reconstruction from serial sections: The anatomical relationship between the tubular and vascular component. J. Ultrastruct. Res., 33: 116 (1970).

3. BARAJAs, L.: Renin secretion: An anatomical basis for tubular control. Science, 172: 485 (1972).

4. Blechner, J. N., Meschia, G., and Barron, D. H.: A study of the acid-base balance of fetal sheep and goats. Quart. J. Exp. Physiol. Congr. Med. Sci., 45: 60 (1960).

5. Boucher, R., Veyrat, R., DeChamplain, J., and Genest, J.: New procedure for measurement of human plasma angiotensin and renin activity levels. Can. Med. Ass. J., 20: 194 (1964).

6. Brown, J. J., Davies, D. L., DoAK, P. B., Lever, A. F., AND ROBERTSON, J. I. S.: Plasma renin in normal pregnancy. Lancet, ii: 900-901 (1963).

7. Brown, J. J., Davies, D. L., Doak, P. B., Lever, A. F., AND RoBerTson, J. I. S.: The presence of renin in human amniotic fluid. Lancet, $i i: 64$ (1964).

8. Capels, K., Dlouka, H., Fernandez, J., And Popp, M.: Regulation of proximal tubule reabsorption in early postnatal period of infant rats. Vol. VII, p. 72. In: Proceedings of the XXIVth International Congress of Physiological Science, Washington, D.C., 1968.

9. Carriere, S., and Friborg, J.: Intrarenal blood flow and PAH extraction during angiotensin infusion. Amer. J. Physiol., 217: 1708 (1969).

10. Соок, W. F.: The detection of renin in juxtaglomerular cells. J. Physiol., 194: 73 (1968).

11. deMartino, C., and Zamboni, L. A.: Morphologic study of the mesonephrons of the human embroyo. J. Ultrastruct. Res., 16: 399 (1966).

12. DoudA, G., AND Endes, P.: Studies on the ontogenesis of granulated cells of the juxtaglomerular apparatus. ACTA Morphol. Acad. Sci. Hung., 12: 51 (1963).

13. Edelman, R., and Hartroft, P. M.: Localization of renin in 
juxtaglomerular cells of rabbit and dog through the use of fluorescent antibody technique. Circ. Res., 9: 1069 (1961).

14. Ferris, T. F., Gorden, P., AND Muldrow, P. J.: Rabbit uterus as a source of renin. Amer. J. Physiol., 212: 698 (1967).

15. Genest, J., DeChamplain, J., Vexrat, R., Boucher, R., Trembloy, G. Y., Strong, C. G., Korw, E., and Marc-Auele, $\mathrm{J} .:$ Role of the renin-angiotensin system in various physiological and pathological states. In: Hypertension: Proceedings of the Counc. on High Blood Pressure. Res. Amer. Heart Ass. Monogr., 13: 97 (1971).

16. Goldblatr, H.: Studies on experimental hypertension due to renal ischemia. Ann. Intern. Med., 69: Il (1937).

17. Granger, P., Roja-Ortega, J. M., Perez, S. C., Boucher, R., AND GENEST, $\mathrm{J}$.: The renin-angiotensin system in newborn dogs. Can. J. Phys. Pharmacol., 49: 134 (1971).

18. Gross, F., Brunner, H., AND ZIEGLER, M.: Renin-angiotensin system, aldosterone and sodium balance. Recent Progr. Hormone Res., 21: 119 (1965).

19. Gruskin, A. B., Edelmann, C. M., and Yuan, S.: Maturational changes in renal blood flow in piglets. Pediat. Res., 4: 7 (1970).

20. Hartroft, P. M., and Hartroft, W. S.: Studies on juxtaglomerular cells. I. Variations produced by sodium chloride and desoxycorticosterone acetate. J. Exp. Med., 97: 415 (1953).

21. Hodari, A. A., Bumpus, F. M., And Smeby, R.: Renin in experimental "Toxemia of pregnancy." Obstet. Gynecol., 30: 8 (1967).

22. Hodari, A. A., and Hodgekinson, C. P.: Fetal kidney as a source of renin in the pregnant dog. Amer. J. Obstet. Gynecol., 102-691 (1968).

23. Horster, M., and Voltin, H.: Postnatal development of renal function; micro puncture and clearance studies in the dog. J. Clin. Invest., 50 (197I).

24. Jose, P. A., Loagn, A. G., Slotkoff, L. M., Libenfield, L. A., Calcagno, P. L., ANd Eisner, G. M.: Intrarenal blood flow distribution in canine puppies. Pediat. Res., 5: 335 (1971).

25. Kotchen, A. L., Strickland, A. L., Rice, T. W., and Walters, D. R.: Renin-angiotensin system in newborn infants. J. Pediat., 80: 839 (1972).

26. LJungquist, A., AND Wagermark, J.: Development of vascular pattern of glomeruli. Arch. Pathol., 82: 403 (1966).

27. LJUNGQuist, A., ANd WAGermark, J.: Renal juxtagolmerular granulation in the human foetus and infant. ACTA Pathol. Microbiol. Scand., 67: 257 (1966).

28. Lupu, A. N., Maxwell, M. A., ANd White, F. N.: Catecholamine releasing agent recovered from plasma of subjects with arterial hypertension. Proc. Exp. Biol. Med., 134: 617 (1970).
29. Osathanondh, V., ANd Potter, E. L.: Development of human kidneys as shown by micro-dissection. IV. Development of tubular portions of nephron. Arch. Pathol., 82: 391 (1966).

30. Rudolph, A. M., and Heymann, M. A.: Circulatory changes during growth in the fetal lamb. Circ. Res., 26: 289 (1970).

31. Skinner, S. L., Lumbers, E. R., ANd Symonds, E. M.: Renin concentration in human fetal and maternal tissues. Amer. J. Obstet. Gynecol., 101: 529 (1968).

32. Skinner, S. L., McCubbin, J. W., and Page, I. H.: Renal baroceptor control of renin secretion. Science, 141: 814 (1963).

33. Smith, F. G., JR., Bashore, R. A., Barajas, L., AND LUPU, A. N.: Renin-angiotensin system in the fetal sheep. Pediat. Res., 6: 416 (1972).

34. Smith, F. G., JR., Bashore, R. A., and Kulvinskas, C.: Renal blood flow in the sheep fetus (Unpublished observations).

35. Sutherland, L. E., and Hartroft, P. M.: Juxtaglomerular cells are present in early melanephroi of the hog embroyo. Anat. Rec., 148: 342 (1964).

36. Thurau, K., and Schnermann, J.: Die Natriumkonzentration an den macula densazellen als regulierender factor fur das glomerulumfiltrat. Klin. Wchnschr., 43: 410 (1965).

37. Trimper, C. E., and Lumbers, E. R.: The renin-angiotensin system in foetal lambs. Pfluegers Arch. Gesamte Menschen Physiol. Tiere, 336: 1 (1972).

38. Tsuda, N., Nickerson, P. A., ANd Molteni, A.: Ultrastructural study of developing juxtaglomerular cells in the rat. J. Lab. Invest., 25: 644 (1971).

39. VANDER, A. J., AND Miller, R.: Control of renin secretion in the anesthetized dog. Amer. J. Physiol., 207: 537 (1964).

40. Statham Medical Instruments, Los Angeles, Calif.

41. Offner Electronics, Inc., Schiller Park, Ill.

42. Siemens Corp., Iselin, N.J.

43. The authors gratefully acknowledge the expert technical assistance of Helga Dammann Lupu, Claudius Kulvinskas, Mike Nathan, and Esther Braden.

44. This work was supported by Research Grants nos. HD 04460 from the National Institute of Child Health and Human Development, HE 11114 and $\mathrm{HE}$ 9575-07 from the National Heart and Lung Institute, and AHA 71994 from the American Heart Association. Dr. A. N. Lupu was the recipient of a Los Angeles County Heart Association Senior Investigatorship.

45. Requests for reprints should be addressed to: F. G. SMrTH, JR., M.D., Department of Pediatrics, University of Iowa School of Medicine, Iowa City, Iowa 52242 (USA)

46. Accepted for publication January 15, 1974. 